\title{
Zinc Fertilization of Cereals for Increased Production and Alleviation of Zinc Malnutrition in India
}

\author{
Rajendra Prasad • Yashbir Singh Shivay • \\ Dinesh Kumar
}

Received: 5 July 2012/Accepted: 2 April 2013/Published online: 7 May 2013

(C) NAAS (National Academy of Agricultural Sciences) 2013

\begin{abstract}
Zinc deficiency has emerged as the fourth important micronutrient deficiency in humans. Zn deficiency is responsible for diarrhoea in infants, dwarfism in adolescents and loss of disability adjusted life years (DALYs) in adults. The loss of DALYs in India is estimated at 2.8 million. Since cereals are staple food in India and other Asian countries, fortification of their grains with $\mathrm{Zn}$ is a simple way to overcome $\mathrm{Zn}$ deficiency in humans in these areas. Efforts are underway to breed cereal cultivars with grains higher in zinc, but this requires considerable time. Fertilization of cereals with $\mathrm{Zn}$ is a faster, quicker and certain way to increase zinc content in cereals and this practice needs to be put in place without any delay.
\end{abstract}

Keywords Foliar application of $\mathrm{Zn} \cdot$ Phytate $\cdot$ Phytate:Zn molar ratio $\cdot \mathrm{Zn}$ fertilization $\cdot \mathrm{Zn}$ malnutrition . Zn deficiency in soil

\begin{abstract}
Abbreviations
BMPs: Best management practices; DALY: Disability adjusted life years; PDS: Public Distribution System; DTPA: Diethylene triamine pentaacetic acid; DW: Dry weight; IRRI: International Rice Research Institute; Mt: Million tonnes; PZMR: Phytate:Zn molar ratio; RWCS: Rice-wheat cropping system; Zn: Zinc; ZnO: Zinc oxide;
\end{abstract}

\section{Introduction}

Globally, three major micronutrient deficiencies have been recognised in humans [2]. The deficiencies are: (i) vitamin A deficiency leading to blindness; about $57 \%$ of preschool children in India have sub-clinical vitamin A deficiency; (ii) iron deficiency leading to anaemia; about $79 \%$ of the kids between 6 and 35 months of age and $56 \%$ of women between 15 and 49 years of age are anaemic in India and (iii) iodine deficiency leading to goitre and cretinism is endemic in $85 \%$ districts in India [19]. The fourth

R. Prasad · Y. S. Shivay $(\bowtie) \cdot$ D. Kumar

Division of Agronomy, Indian Agricultural Research Institute,

New Delhi 110 012, India

e-mail: ysshivay@hotmail.com micronutrient deficiency of $\mathrm{Zn}$ has recently received global attention. Some data on global mortality in children under 5 years of age due to different micronutrient deficiencies in 2004 are given in Table 1 . Zn deficiency was next only to vitamin A deficiency and was responsible for over 453 thousand deaths. Zinc deficiency leads to diarrhoea and pneumonia in children $[3,7,9]$. Childhood dwarfism is considered as indication of $\mathrm{Zn}$ deficiency and about 61 million children under the age of 15 years are reported to be dwarf [13]. Zn plays an important role in production of proteins and thus helps in wound healing, blood formation and growth and maintenance of tissue [2]. Stein et al. [32] using DALYs (disability adjusted life years) showed that $\mathrm{Zn}$ deficiency in India is a highly relevant health problem and is responsible for a loss of 2.8 million DALYs per 
annum. They observed that biofortification of cereals (rice and wheat) may reduce this burden by $20-51 \%$ and save 0.6-1.4 million DALYs each year. Importance of $\mathrm{Zn}$ in human nutrition and health has received some attention in India in recent years [18, 19, 33].

Cereals are the staple food in India and meet $60 \%$ of the energy and protein needs of humans in the country (Table 2). As a contrast in developing countries such as the USA, cereals meet only a little over $20 \%$ of the energy and protein needs of humans $[6,17]$. Of the cereals rice and wheat make up a little over $80 \%$ of the total cereals production in the country and are distributed through Public Distribution System (PDS) of the Govt. of India. Although un-hulled rice (paddy) contains 27-42 $\mathrm{mg} \mathrm{Zn} \mathrm{kg}^{-1}$ grain [25], the polished rice contains only 13-15 $\mathrm{mg} \mathrm{Zn} \mathrm{kg}^{-1}$ grain [36], while wheat grains contain 38-47 mg Zn kg ${ }^{-1}$ [26]. A diet of 300-400 $\mathrm{g}_{\text {cereals day }}{ }^{-1}$ will supply only 4-6 $\mathrm{mg} \mathrm{Zn} \mathrm{day}^{-1}$ in the case of rice and 11-18 mg Zn day ${ }^{-1}$ in the case of wheat. However, only a part of the $\mathrm{Zn}$ present in cereals is bio-available due to the presence of phytates. The phytate content varies from 0.14 to $0.60 \%$ in rice and $0.39-1.35 \%$ in wheat (Wikipedia Int.). Animal proteins contain higher amounts of $\mathrm{Zn}$ and also do not contain phytates and are therefore a better source of $\mathrm{Zn}$. Animal proteins, however, form a very small part of Indian diet. Gibson [8] reported that a PZMR (phytate:Zn molar ratio) above 15 in foods is associated with reduced $\mathrm{Zn}$ bioavailability. The recommended dietary allowance for humans is $15 \mathrm{mg} \mathrm{Zn} \mathrm{day}{ }^{-1}$ for adult males and $12 \mathrm{mg} \mathrm{Zn} \mathrm{day}^{-1}$ for adult females (16-19 $\mathrm{mg} \mathrm{Zn} \mathrm{day}^{-1}$ for breast feeding women) [35]. Fortification of cereal grains with $\mathrm{Zn}$ either by $\mathrm{Zn}$ fertilization of these crops or development of $\mathrm{Zn}$ efficient cultivars of these crops is therefore important from the viewpoint of food security as well as nutritional security.

\section{Area, Production and Productivity of Cereals in India}

Over the past 60 years (1950-2010), the total area under cereals has increased from 78.2 million hectares $(\mathrm{M}$ ha) in 1950-1951 to $98 \mathrm{M}$ ha in 2009-2010 (Table 2). The increase was most in wheat (193\%), followed by that in maize $(159 \%)$ (Fig. 1). The area under rice during this period increased by $36 \%$, while that under pearl millet was

Table 1 Global mortality in children under 5 years of age in 2004

Source Black et al. [3]

\begin{tabular}{lr}
\hline Deficiency & \multicolumn{1}{c}{ Deaths } \\
\hline Vitamin A & 666,771 \\
Zinc & 453,207 \\
Iron & 20,854 \\
Iodine & 3,619 \\
\hline
\end{tabular}

negligible $(1.1 \%)$. On the contrary, the area under sorghum declined by $50 \%$. As regards production of cereals during the same period, it increased by $380 \%$ (Fig. 2). The largest increase was in wheat $(1,143 \%)$, followed by maize $(882 \%)$ and rice $(201 \%)$. The increase in the production of sorghum, despite $50 \%$ reduction in area was $4 \%$, while that in pearl millet was $2.5 \%$. This is why India's Green Revolution is mainly considered as wheat revolution. As compared to 1950-1951, the productivity in 2009-2010 increased four-fold in wheat, 3.7-fold in maize, 3 -fold in rice and about 2.5 -fold in pearl millet and sorghum (Fig. 3). This enormous increase in productivity and production was possible due to a massive programme in developing high yielding hybrids and varieties of crops and a matching research in crop agronomy resulting in the development of best management practices (BMPs) for different cereals for the different regions of the country.

However, in conventional breeding the emphasis has been on grain yield and not much attention was attached to the concentration of nutrients including micronutrients, which, in general, decline as the yield increases [37]. Also there have been efforts to breed cultivars capable of growing on $\mathrm{Zn}$ stress soils. This all led to the development of crop cultivars with lower concentration of $\mathrm{Zn}$ in grain as well as straw.

\section{Zinc Deficiency in Indian Soils}

Zinc malnutrition achieves great significance in India because nearly half of the Indian soils are poor in available $\mathrm{Zn}$. Percentage of soil samples deficient in DTPAextractable available $\mathrm{Zn}$ varies from $8 \%$ in Puducherry to $78 \%$ in Maharashtra (Table 3). Zn deficiency is less prevalent in the western states of Rajasthan and Gujarat. Zn deficiency was first detected in rice at Pantnagar, Uttarakhand in 1965 by Nene [15]. There has been great emphasis on $\mathrm{Zn}$ fertilization in rice and wheat in northwestern India and as a result now the soils in the northern states of Punjab, Haryana and western Uttar Pradesh have a low percentage of $\mathrm{Zn}$ deficient soils. More than $90 \%$ of $\mathrm{Zn}$ in soils occurs as insoluble $\mathrm{Zn}$ and is unavailable to plants, while exchangeable $\mathrm{Zn}$ ranges from 0.1 to $2 \mathrm{mg} \mathrm{kg}^{-1}$ soil [28]. Soluble $\mathrm{Zn}$ in bulk soil solution generally varies from $4 \times 10^{-10} \mathrm{M}$ to $4 \times 10^{-6} \mathrm{M}$ [1]. In calcareous soils such as those found in the rice-wheat cropping system (RWCS) belt in India, soluble $\mathrm{Zn}$ concentration may be as low as $10 \times 10^{-9} \mathrm{M}$ and can limit plant growth [11]. The soil factor most affecting the availability of $\mathrm{Zn}$ is $\mathrm{pH}$. In a study at Bhopal desorption of adsorbed $\mathrm{Zn}$ decreased with increasing $\mathrm{pH}$ and stopped abruptly at $\mathrm{pH} 7.5$ [23]. Alternate flooding and drying as obtained under irrigated rice culture also results in increased desorption of $\mathrm{Zn} \mathrm{[24].}$ 
Table 2 Area, production and productivity of cereals in India

\begin{tabular}{|c|c|c|c|c|c|c|c|}
\hline Year & Rice & Wheat & Sorghum & Pearl millet & Maize & Total cereals* & $\begin{array}{l}\text { Rice }+ \text { wheat } \\
(\% \text { of total cereals })\end{array}$ \\
\hline \multicolumn{8}{|c|}{ Area (million hectares) } \\
\hline $1950-1951$ & 30.8 & 9.7 & 15.6 & 9.0 & 3.2 & 78.2 & 51.8 \\
\hline $1970-1971$ & 37.6 & 18.2 & 17.4 & 12.9 & 5.8 & 101.8 & 54.8 \\
\hline 1990-1991 & 42.7 & 24.2 & 14.4 & 10.5 & 5.9 & 103.2 & 64.8 \\
\hline $2009-2010$ & 41.9 & 28.4 & 7.8 & 8.9 & 8.3 & 98.0 & 71.7 \\
\hline \multicolumn{8}{|c|}{ Production (million tonnes) } \\
\hline $1950-1951$ & 29.6 & 6.5 & 5.5 & 2.6 & 1.7 & 42.4 & 85.1 \\
\hline $1970-1971$ & 42.2 & 23.8 & 8.1 & 8.0 & 7.5 & 96.6 & 63.3 \\
\hline 1990-1991 & 74.3 & 55.1 & 11.7 & 6.9 & 9.0 & 162.1 & 79.8 \\
\hline 2009-2010 & 89.1 & 80.8 & 6.7 & 6.5 & 16.7 & 203.4 & 83.5 \\
\hline \multicolumn{8}{|c|}{ Productivity $(\mathrm{kg} / \mathrm{ha})$} \\
\hline $1950-1951$ & 668 & 663 & 353 & 288 & 547 & 542 & - \\
\hline 1970-1971 & 1,123 & 1,307 & 466 & 622 & 1,279 & 949 & - \\
\hline 1990-1991 & 1,740 & 2,281 & 814 & 658 & 1,518 & 1,571 & - \\
\hline 2009-2010 & 2,125 & 2,839 & 860 & 731 & 2,024 & 2,075 & - \\
\hline
\end{tabular}

* Total for cereals includes minor millets such as ragi etc

Fig. 1 Percentage increase/ decrease in area of cereal crops during 2009-2010 over 1950-1951

Fig. 2 Percentage increase/ decrease in production of cereal crops during 2009-2010 over 1950-1951
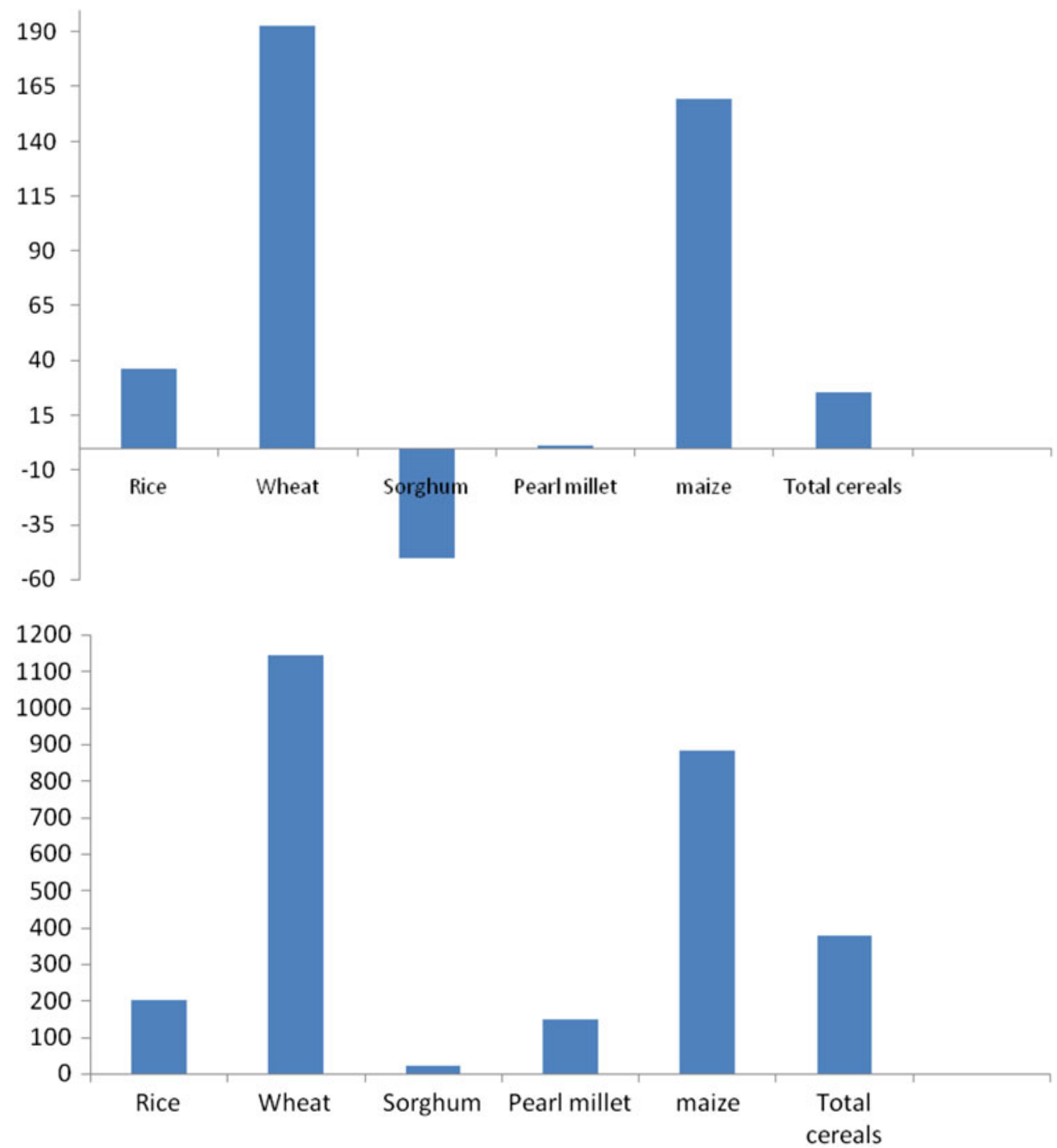
Fig. 3 Times increase in the productivity of cereal crops during 2009-2010 over 1950-1951

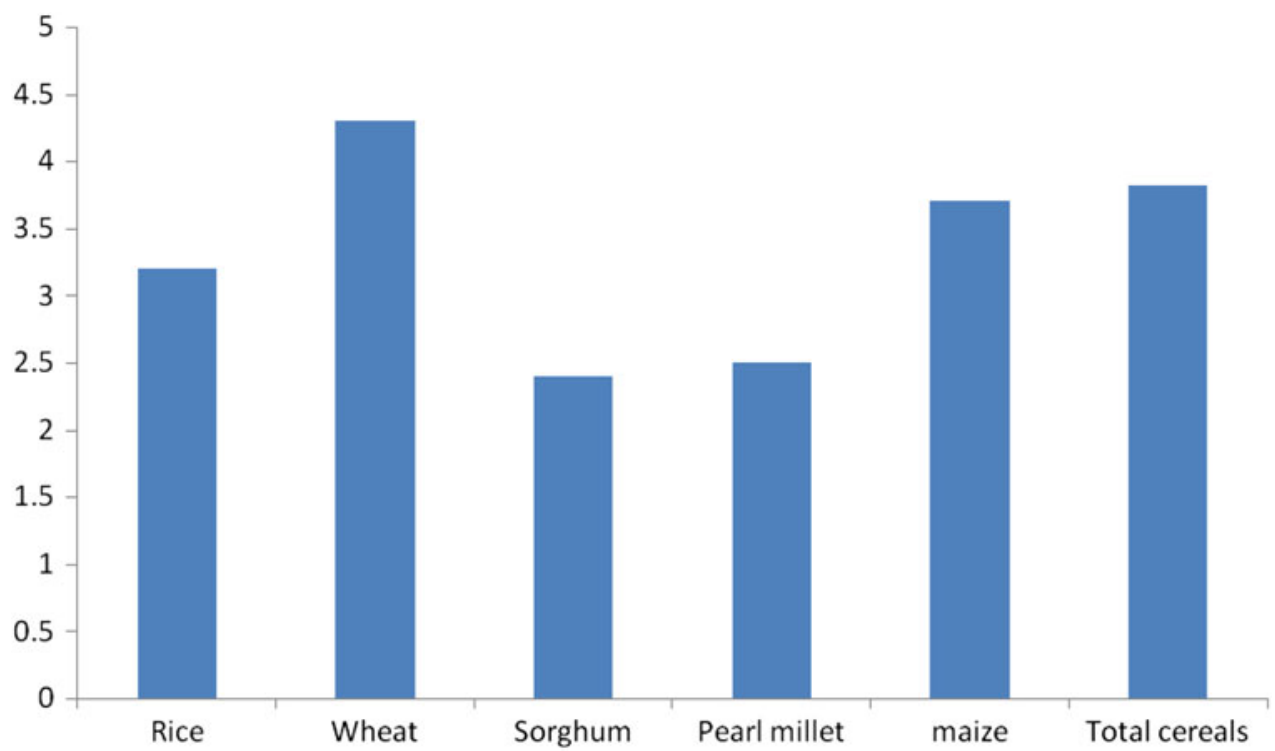

Table 3 Extent of $\mathrm{Zn}$ deficiency in soils of different states of India

\begin{tabular}{ll}
\hline Region & State (\% of samples deficient in available Zn) \\
\hline Eastern & Assam (34.0), Bihar \& Jharkhand (65.3), Orissa (51.0), West Bengal (36.0), Chhattisgarh (63.0) \\
Northern & Punjab (24.6), Haryana (26.4), Uttar Pradesh (38.9), Uttarakhand (28.0), Himachal Pradesh (42.0), J\&K (12.0) \\
Western and Central & Madhya Pradesh (65.8), Maharashtra (78.0), Rajasthan (21.0), Gujarat (19.9) \\
Southern & Andhra Pradesh (46.7), Tamil Nadu (71.4), Karnataka (72.8), Kerala (34.0\%) \\
\hline
\end{tabular}

Table 4 Critical limits of DTPA extractable $\mathrm{Zn}\left(\mathrm{mg} \mathrm{kg}^{-1}\right.$ soil) for cereals for different major soils

\begin{tabular}{lllll}
\hline Soil & Rice & Wheat & Maize & Sorghum \\
\hline Alluvial & $0.38-0.90$ & $0.40-0.80$ & $0.54-1.00$ & - \\
Black & $0.84-1.34$ & 0.54 & - & - \\
Red and Black & $0.45-2.00$ & $0.46-0.60$ & $1.00-2.00$ & $1.00-2.00$ \\
Red & $0.60-1.00$ & - & $0.65-0.80$ & - \\
\hline
\end{tabular}

Table $5 \mathrm{Zn}$ recommendations for corn in Minnesota (USA)

\begin{tabular}{lll}
\hline $\begin{array}{l}\text { DTPA extractable } \\
\mathrm{Zn}\left(\mathrm{mg} \mathrm{kg}^{-1} \text { soil }\right)\end{array}$ & $\begin{array}{l}\text { Starter } \\
\left(\mathrm{kg} \mathrm{ha}^{-1}\right)\end{array}$ & $\begin{array}{l}\text { Broadcast } \\
\left(\mathrm{kg} \mathrm{ha}^{-1}\right)\end{array}$ \\
\hline $0.00-0.25$ & 2 & 10 \\
$0.25-0.50$ & 2 & 10 \\
$0.51-0.75$ & 1 & 5 \\
$0.75-1.00$ & 0 & 0 \\
1.01 & 0 & 0 \\
\hline
\end{tabular}

The critical limits of DTPA extractable $\mathrm{Zn}$ vary from 0.38 to $2 \mathrm{mg} \mathrm{kg}^{-1}$ for different soils and crops (Table 4) [34]. $\mathrm{Zn}$ application is recommended when soils have available $\mathrm{Zn}$ level below the critical level. In this context $\mathrm{Zn}$ fertilizer recommendations for corn and some other crops in the state of Minnesota (USA) are worth taking note of (Table 5), because the $\mathrm{Zn}$ application recommendations are staggered on the basis of soil test and are not made simply on the basis of critical level.

\section{Zn Deficiency Symptoms in Plants}

Since $\mathrm{Zn}$ is associated with several enzymes, its deficiency leads to several disorders in plants. Also since $\mathrm{Zn}$ is relatively immobile in plants, its deficiency symptoms generally appear on the growing young tissue. The essentiality of $\mathrm{Zn}$ was first shown by Maze [14] in maize, where it is known as 'white bud'. As already pointed out, its deficiency in rice was first reported by Nene [15] at the G. B. Pant University of Agriculture and Technology, Pantnagar. In rice the characteristic symptoms are bronzing 
Table 6 Relative tolerance of rice genotypes to $\mathrm{Zn}$ stress

\begin{tabular}{lcl}
\hline Class & \% Response to applied Zn & Genotypes \\
\hline Highly susceptible & $103-237$ & Sita, IR 36, Pankaj, Radha, Saket 4 \\
Susceptible & $40-78$ & Prabhat, SBR 3025 \\
Moderately tolerant & $12-20$ & Rajshree, RAU 1326-29-3-1, Kanka, Mashuri \\
Tolerant & $5-10$ & TCA 177, Vaidehi \\
\hline
\end{tabular}

Table $7 \mathrm{Zn}$ deficiency scores of some common IRRI rice cultivars at IRRI

\begin{tabular}{lllll}
\hline Cultivar & $\begin{array}{l}\text { Observations } \\
\text { (Nos.) }\end{array}$ & $\begin{array}{l}\text { Minimum } \\
\text { score }\end{array}$ & $\begin{array}{l}\text { Maximum } \\
\text { score }\end{array}$ & SD \\
\hline IR 42 & 159 & 1 & 9 & 1.78 \\
IR 36 & 152 & 1 & 9 & 1.74 \\
IR 20 & 47 & 3 & 9 & 1.82 \\
IR 8 & 45 & 3 & 9 & 1.49 \\
IR 54 & 35 & 3 & 9 & 1.16 \\
\hline
\end{tabular}

Table 8 Relative tolerance of wheat genotypes to $\mathrm{Zn}$ stress

\begin{tabular}{lll}
\hline Class & $\begin{array}{l}\text { \% Response } \\
\text { to applied Zn }\end{array}$ & Genotypes \\
\hline $\begin{array}{l}\text { Triticum aestivum } \\
\text { Highly susceptible }\end{array}$ & $27-29$ & PBW 343, WH 747 \\
Moderately susceptible & $11-28$ & $\begin{array}{l}\text { WH 542, HD 2009, } \\
\text { HD 2329, } \\
\text { HP 1731 }\end{array}$ \\
$\begin{array}{l}\text { Less susceptible } \\
\text { Triticum durum }\end{array}$ & $7-10$ & UP 2338, WH 157 \\
Highly susceptible & $36-46$ & WH 912, PDW 215 \\
Moderately susceptible & $17-36$ & WH 896, PDW 233, \\
& & HD 4502, MACS 2846 \\
Less susceptible & $13-17$ & Raj 1555, PBW 34 \\
\hline
\end{tabular}

starting with young leaves and then spreading to other plant parts. The disease was given the name Khaira due to dark brown colour similar to Khair. In severe Zn deficiency, dark brown patches of stunted rice plants appear in the field. In wheat, bronzing is not so evident and necrosis in leaves and stunting are more obvious symptoms.

\section{Critical Levels in Rice and Wheat Tissue}

Yoshida et al. [41] established the following criteria ( $\mathrm{mg} \mathrm{Zn} \mathrm{kg}{ }^{-1}$ whole plant tissue DM) for Zn deficiency in rice: $<10$ definite deficiency, $10-15$ very likely deficiency, 15-20 likely deficiency and $>20$ unlikely deficiencies. In India, Srivastava et al. [30] reported a critical limit of $23.6 \mathrm{mg} \mathrm{kg}^{-1} \mathrm{DW}$ of the 3rd fully open leaf from the top at 60 days after transplanting for the rice cultivar Jaya, while it was $23 \mathrm{mg} \mathrm{kg}^{-1}$ DW for the rice cultivar PD-4. Thus, rice cultivars differ in their tolerance to $\mathrm{Zn}$ deficiency and a list of highly deficient to tolerant ones at Pantnagar are given in Table 6. Even intra-cultivar variations exist and IRRI has prepared a data base for this. Some data on popular IRRI rice cultivars are given in Table 7. The reasons for intra-cultivar include variation in the magnitude of the stress over space and time, genotype $\times$ environment variation, involvement of a large number of genes and low heritability of genes [20]. Wissuwa et al. [39] observed that native soil $\mathrm{Zn}$ status was an important factor in determining $\mathrm{Zn}$ concentration in rice grains and depending upon soil $\mathrm{Zn}$ status, grain $\mathrm{Zn}$ concentration could vary from 8 to $47 \mathrm{mg} \mathrm{kg}^{-1}$ grain in a single genotype.

As in rice, wheat cultivars also differ in their effectiveness in utilizing native soil $\mathrm{Zn}[4,22,29]$. Some data from Pantnagar are in Table 8. In India Takkar et al. [34] gave a critical limit of $8-12 \mathrm{mg} \mathrm{Zn} \mathrm{kg}^{-1} \mathrm{DW}$ in whole tissue of wheat, while Srivastava et al. [30] reported a value of $18.4 \mathrm{mg} \mathrm{Zn} \mathrm{kg}^{-1}$ DW in flag leaf at 60 days after sowing.

\section{Response of Cereals to Zn Fertilization}

Reviewing the data from several research centres in India, Rattan et al. [21] reported an average response $\left(\mathrm{kg} \mathrm{ha}^{-1}\right)$ of 760 in rice, 670 in maize, 380 in wheat, 480 in sorghum and 210 in pearl millet. Similar but slightly lesser response of cereals to $\mathrm{Zn}$ fertilization was reported by Patel [16]. Based on these average responses of cereals to $\mathrm{Zn}$ Shukla and Behera [27] predicted that additional production due to $\mathrm{Zn}$ fertilization could be $11.86,3.53,1.3 \mathrm{Mt}$ in rice, $0.28 \mathrm{Mt}$ in sorghum and $0.19 \mathrm{Mt}$ in pearl millet. Thus, total increase in cereal production in India due to $\mathrm{Zn}$ fertilization could be about $17 \mathrm{Mt}$, which is $7.6 \%$ of the total cereal production in 2010-2011. Thus, adequate $\mathrm{Zn}$ fertilization can certainly help in increasing cereal production in the country.

\section{Biofortification of Cereals with $\mathrm{Zn}$}

In view of the emergence of $\mathrm{Zn}$ as an important nutritional problem, especially in the developed countries, the need for genetic biofortification of cereals by developing cultivars with higher $\mathrm{Zn}$ (and other micronutrients) contents in 
Fig. 4 Grain $\mathrm{Zn}$ concentration in rice and wheat due to degree of $\mathrm{Zn}$ enrichment of urea. Solid lines for $\mathrm{Zn}$ sulphate (ZnSEU) and dotted lines for $\mathrm{Zn}$ oxide enriched urea ( $\mathrm{ZnOEU})$ grains was mooted by Graham [10]. Their findings led to the development of programmes such as HarvestPlus, Golden Rice and African Biofortified Sorghum Project focusing on the development of crop varieties capable of producing grains higher in $\mathrm{Zn}$ and other micronutrients contents [31]. Such programmes require fairly long time and so far no $\mathrm{Zn}$ rich cultivar in any cereal has become available. Further such cultivars may not be high yielding. Combining high grain yield and high $\mathrm{Zn}$ concentration in grain needs still more time. Also the produce from newly developed cultivars may not be acceptable to consumers, who have their own preferences.

On the contrary agronomic biofortification through $\mathrm{Zn}$ fertilization (also referred to as ferti-fortification) results in increased grain production as well as higher $\mathrm{Zn}$ concentration in grains at the same time [19]. Even cultivars
Rice

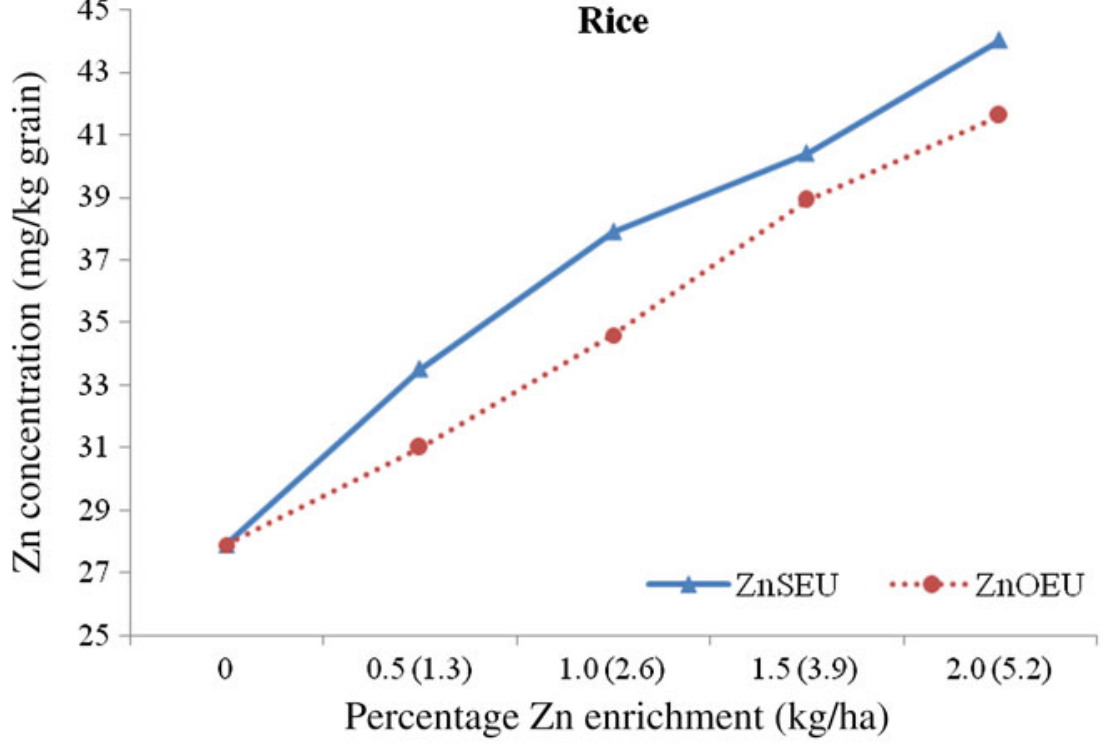

Wheat

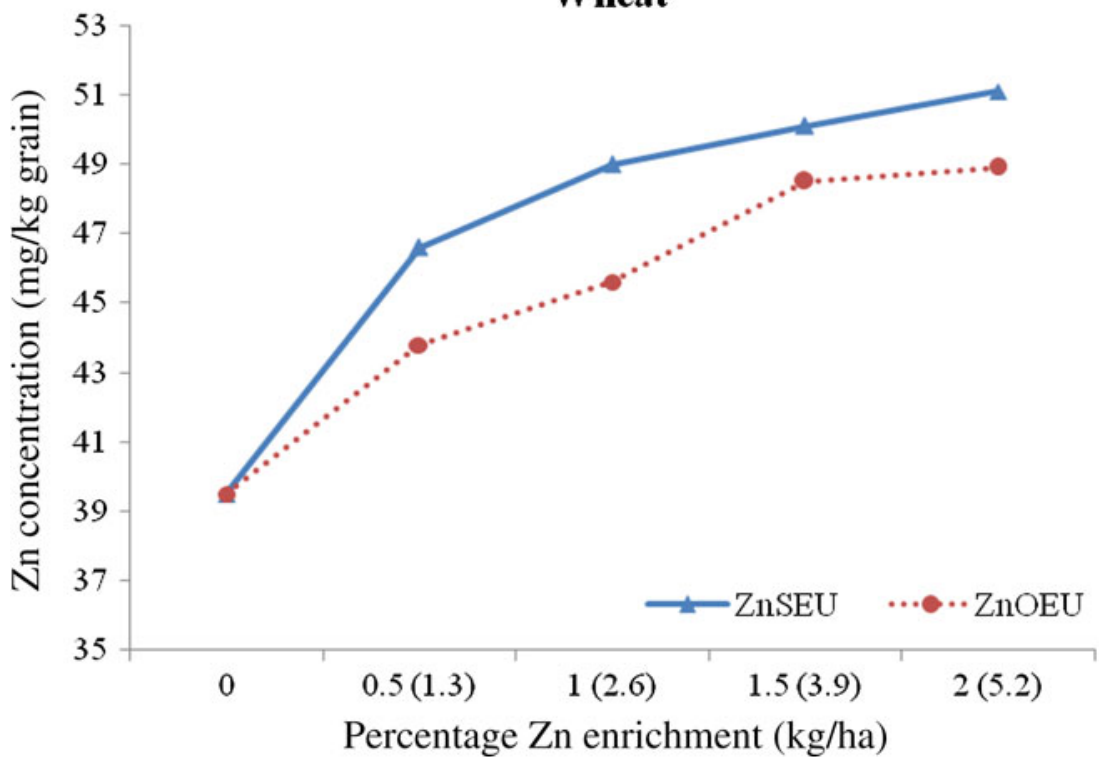

developed by genetic biofortification will need $\mathrm{Zn}$ fertilization.

Work on agronomic biofortification of cereals (rice and wheat) in India was started by our group at the Indian Agricultural Research Institute, New Delhi with the availability of zinc enriched urea using zinc sulphate or $\mathrm{ZnO}$ from a fertilizers company. Grain yield of rice as well as wheat increased as the degree of $\mathrm{Zn}$ enrichment of urea was increased from 0.5 to $2.0 \%$ (equivalent to an application of $1.3-5.2 \mathrm{~kg} \mathrm{Zn} \mathrm{ha}^{-1}$ ). $\mathrm{Zn}$ enrichment of urea @ $2 \% \mathrm{Zn}$ as zinc sulphate increased the grain yield of rice by $29.4 \%$ and that of wheat by $19.1 \%$. As compared to the grain yield the increase in grain $\mathrm{Zn}$ concentration was much more. Zn enrichment of urea @2\% Zn as zinc sulphate increased the grain $\mathrm{Zn}$ concentration by $61.8 \%$ in rice and by $51.1 \%$ in wheat; the actual value 
(mg $\mathrm{Zn} \mathrm{kg}^{-1}$ grain) was $47.4 \%$ with $\mathrm{Zn}$ fertilization and $29.3 \%$ without $\mathrm{Zn}$ in rice (Fig. 4). The corresponding value (mg $\mathrm{Zn} \mathrm{kg}^{-1}$ grain) in wheat was 51.1 with $\mathrm{Zn}$ fertilization and 39.5 without $\mathrm{Zn}$. Zn sulphate was better than $\mathrm{ZnO}$ for $\mathrm{Zn}$ enrichment of urea, both in respect of grain yield as well as grain $\mathrm{Zn}$ concentration. This was mainly due to zinc sulphate being water soluble, while $\mathrm{ZnO}$ is not water soluble. Westfall and Gangloff [38] reported that the effectiveness of six granulated $\mathrm{Zn}$ fertilizers decreased as the per cent water soluble $\mathrm{Zn}$ decreased in them and they observed that at least $50 \%$ water soluble $\mathrm{Zn}$ was desirable. To achieve this $\mathrm{Zn}$ fertilizer manufacturers in USA are using a mixture of $\mathrm{ZnO}$ and zinc sulphate for enriching fertilizers with $\mathrm{Zn}$. Such fertilizers are referred to as $\mathrm{Zn}$ oxysulphates.

Hossain et al. [12] from Jessore (Bangladesh) reported that $\mathrm{Zn}$ application increased grain $\mathrm{Zn}$ concentration in maize by $73 \%$ and in rice by $141 \%$. The actual values (mg Zn kg ${ }^{-1}$ grain) for maize were 28.4 for $\mathrm{Zn}$ fertilized (@ $4 \mathrm{~kg} \mathrm{ha}^{-1}$ ) crop as against 16.5 for no $\mathrm{Zn}$ control. Similarly, the grain $\mathrm{Zn}$ concentration ( $\mathrm{mg} \mathrm{Zn} \mathrm{kg}{ }^{-1}$ grain) in rice was 50.0 for $\mathrm{Zn}$ fertilized (@2 kg Zn ha ${ }^{-1}$ ) crop as against 20.7 for no $\mathrm{Zn}$ control.

Yang et al. [40] from Yangling (China), reported that soil $\mathrm{Zn}$ application had mixed effect in increasing grain $\mathrm{Zn}$ concentration in wheat; it increased by $21 \%$ in some cultivars, while it decreased it in other cultivars. However, foliar application of $\mathrm{Zn}$ increased grain $\mathrm{Zn}$ concentration in all wheat cultivars ranging from 26 to $115 \%$. Grain $\mathrm{Zn}$ concentration in wheat ranged from 33.3 to $59.7 \%$. Dhaliwal et al. [5] from Ludhiana also reported a significant increase in grain $\mathrm{Zn}$ concentration due to foliar application of $0.5 \%$ zinc sulphate solution. The cultivars, however, differed in their response to foliar $\mathrm{Zn}$ application; the increase was $44.8 \%$ in PR $116,42.4 \%$ in PR 115 , $40.6 \%$ in PR 114, $39.3 \%$ in PASU 201 and $30.8 \%$ in PR 113. The $\mathrm{Zn}$ concentration in rice grain was $47 \%$ in $\mathrm{Zn}$ fertilized crop as against $33.8 \%$ in no $\mathrm{Zn}$ control.

Yang et al. [40] also reported that application of $\mathrm{Zn}$ reduced phytate concentration and phytate: $\mathrm{Zn}$ molar ratio in wheat grain. The actual values for phytic acid were $8.13 \mathrm{~g} \mathrm{~kg}^{-1}$ grain as against 7.01 in unfertilized crop. $\mathrm{Zn}$ fertilization reduced phytate: $\mathrm{Zn}$ molar ratio from 23.38 in unfertilized crop to 13.74 and this brought the phytate: $\mathrm{Zn}$ molar ratio in $\mathrm{Zn}$ fertilized wheat below the level of 15 , above which the bioavailability of $\mathrm{Zn}$ is reduced [9].

\section{Conclusions}

- This review brings out that agronomic biofortification is an effective and faster method for increasing grain $\mathrm{Zn}$ concentration in cereals.
- Since cereals are staple food in most developing countries in Asia including India, $\mathrm{Zn}$ fortification of cereal grains benefits all including the poorest of the poor.

- Zinc fertilization has great relevance to India, because about half of its soils are deficient in available $\mathrm{Zn}$.

\section{References}

1. Barber SA (1995) Soil nutrient bioavailability, 2nd edn. Wiley, New York

2. Bell DW, Dell B (2008) Micronutrients for sustainable food, feed, fibre and bioenergy products. International Fertilizer Industry Association, Paris, p 175

3. Black RE, Lindsay HA, Bhutta ZA, Caulfield LE, DeOnnis M, Ezzat M, Mathers F, Rivera J (2008) Maternal and child under nutrition: global and regional exposures and health consequences. Lancet 371:243-260

4. Cakmak I, Gulut KY, Marschner H, Graham RD (1994) Effect of zinc and iron deficiency on phytosiderophore release in wheat genotypes differing in zinc efficiency. J Plant Nutr 17:1-17

5. Dhaliwal SS, Sadana US, Khurana MPS, Manchanda JS (2010) Enrichment of rice grain with zinc and iron through fertilization. Indian J Fertil 6(7):28-35

6. FAO (1996) The Sixth World Food Survey. FAO, Rome

7. Fischer WCL, Black RE (2007) Functional indicators for assessing zinc deficiency. Food Nutr Bull 28(3 Suppl):S454S479

8. Gibson RS (2005) Dietary strategies to enhance micronutrient adequacy: experiences in developing countries. In: Anderson P, Tuladhar JK, Kakri KB, Maskey SL (eds) Micronutrients in South and Southeast Asia. International Centre for Integrated Mountain Development, Kathmandu, pp 3-7

9. Graham RD (2008) Micronutrient deficiencies in crops and their global significance. In: Alloway BJ (ed) Micronutrient deficiencies in global crop production. Springer, Dordrecht, pp 41-61

10. Graham RD, Welch RM, Bouis HE (2001) Addressing micronutrient malnutrition through enhancing the nutritional quality of staple foods: principles, perspectives and knowledge gaps. Adv Agron 70:77-142

11. Harisalihoghu G, Kochian LV (2003) How do some plant tolerate low levels of soil zinc? Mechanisms of zinc affecting in crop plants. New Phytol 159:341-350

12. Hossain MA, Jahiruddin M, Islam SR, Mian MH (2008) The effect of zinc for improvement of crop yield and mineral nutrition in maize-mungbean-rice system. Plant Soil 306:13-22

13. Hotz C, Brown KH (2004) Assessment of the risk of zinc deficiency in populations and options for its control. Food Nutr Bull 25:194-204

14. Maze P (1915) Ferment formen!que. Fermentation forménique de l'acétone. Procédé de culture simple du ferment. Competes Rend Soc Biol (Paris) 78:308-405

15. Nene YL (1966) Symptoms, causes and control of khaira disease of paddy. Bull Ind Phytopath Soc 3:97-101

16. Patel KP (2011) Crop response to zinc-cereal crops. Indian J Fertil 7(10):84-100

17. Prasad R (2003) Protein-energy malnutrition in India. Fertil News 48(4):13-26

18. Prasad R (2006) Zinc in soil and in plant, human and animal. Indian J Fertil 2(9):103-119 
19. Prasad R (2009) Ferti-fortification of grains: an easy option to alleviate malnutrition of some micronutrients in human beings. Indian J Fertil 5(12):129-133

20. Quijano-Guerta C, Kirk GJD, Portugal AM, Bartolome VI, McLaren GC (2002) Tolerance of rice germplasm to zinc deficiency. Field Crops Res 76:123-130

21. Rattan RK, Datta SP, Katyal JC (2008) Micronutrient management-research achievements and future challenges. Indian J Fertil 4(12):93-118

22. Rengel Z, Graham RD (1995) Importance of seed zinc content for wheat growth on zinc-deficient soil. I. Vegetative growth. Plant Soil 173:259-266

23. Rupa TR, Tomar KP (1999) Zinc desorption kinetics as influenced by $\mathrm{pH}$ and phosphorus in soils. Commun Soil Sci Plant Anal 30:1951-1962

24. Rupa TR, Tomar KP, Reddy DD, Rao AS (2000) Time-dependent zinc desorption in soils. Commun Soil Sci Plant Anal 31(15\&16):2547-2563

25. Shivay YS, Kumar D, Prasad R, Ahlawat IPS (2008) Relative yield and zinc uptake by rice from zinc sulphate and zinc oxide coating onto urea. Nutr Cycle Agroecosyst 80:181-188

26. Shivay YS, Prasad R, Rahal A (2008) Relative efficiency of zinc oxide and zinc sulphate-enriched urea for spring wheat. Nutr Cycle Agroecosyst 82:259-264

27. Shukla AK, Behera SK (2012) Micronutrient fertilizers for higher productivity. Indian J Fertil 8(4):100-117

28. Singh MV (2011) Assessing extent of zinc deficiency for soil factors affecting and nutritional scarcity in humans and animals. Indian J Fertil 7(10):36-43

29. Singh B, Netasan SKA, Singh BK, Usha K (2005) Improving zinc efficiency of cereals under zinc deficiency. Curr Sci 88(1):36-44

30. Srivastava PC, Singh SK, Mishra B (2006) Crop response and profitability to applied secondary and micronutrients in cereals. Indian J Fertil 2(8):45-51

31. Stein AJ (2009) Global impacts of human mineral nutrition. Plant Soil 321:117-152
32. Stein AJ, Nestel P, Meenakshi JV, Qaim M, Sachdev HPS, Bhutta ZA (2007) Plant breeding to control zinc deficiency in India: how cost effective is biofortification. Public Health Nutr 106:492-501

33. Takkar PN (2011) Zinc in human and animal health. Indian $\mathbf{J}$ Fertil 7(10):46-66

34. Takkar PN, Singh MV, Ganeshmurthy AN (1997) A critical review of plant nutrient supply needs, efficiency and policy issues for Indian agriculture for the year 2000: micronutrients and trace elements. In: Kanwar JS, Katyal JC (eds) Plant nutrient, supply efficiency and policy issues: 2000-2025. National Academy of Agricultural Sciences, New Delhi, pp 238-264

35. USDA (1996) Dietary allowances for Americans. USDA, Hyattsville

36. Welch RM (2005) Harvesting health: agricultural linkages for improving human nutrition. In: Anderson P, Tuladhada JK, Karki KB, Maskey SL (eds) Micronutrients in south and Southeast Asia. International Centre for Integrated Mountain Development, Kathmandu, pp 9-10

37. Welch RM, Grahm RD (2004) Breeding for micronutrients in staple food crops from a human nutrition perspective. J Exp Bot 55:353-364

38. Westfall D, Gangloff B (2001) Zinc fertilizers-is there a difference? Agron News 21(6):8

39. Wissuwa M, Ismail AM, Graha RD (2008) Rice grain zinc concentrations as affected by genotypes, native soil-Zn availability and zinc fertilization. Plant Soil 306:37-48

40. Yang XW, Tian XH, Gale WJ, Cao YX, Lu XC, Zhao AQ (2011) Effect of soil and foliar zinc application on zinc concentration and bioavailability in wheat grain grown potentially zinc deficient soil. Cereal Res Commun 39:535-543

41. Yoshida S, DA Ahn Forno (1973) Occurrence, diagnosis and correction of zinc deficiency of lowland rice. Soil Sci Plant Nutr 19:83 